\title{
Perceptions of nurses about the implementation of the nursing process in an intensive unit
}

Percepções dos enfermeiros acerca da implementação do processo de enfermagem em uma unidade intensiva

Percepciones de enfermeras sobre la aplicación del proceso de enfermería en una unidad intensiva

\section{Alexsandra Martins da Silva ${ }^{a}$ Aline Daiane Colaço ${ }^{a}$ Camila Vicente $^{a}$ Kátia Cilene Godinho Bertoncello ${ }^{b}$ Lúcia Nazareth Amante ${ }^{b}$ Mabel Villa Demetrioa}

\section{How to cite this article:} Silva AM, Colaço AD, Vicente C, Bertoncello KCG, Amante LN, Demetrio MV. Perceptions of nurses about the implementation of the nursing process in an intensive unit. Rev Gaúcha Enferm. 2021;42:e20200126. doi: https://doi. org/10.1590/1983-1447.2021.20200126 a Universidade Federal de Santa Catarina (UFSC) Florianópolis, Santa Catarina, Brasil.

- Universidade Federal de Santa Catarina (UFSC), Departamento de Enfermagem. Florianópolis, Santa Catarina, Brasil.

\section{ABSTRACT}

Objective: To understand the nurses' perception about the implementation of the nursing process in an Intensive Care Unit. Method: Qualitative, exploratory, and descriptive study. Data collection took place from February to March/2018, in an Intensive Care Unit of a public hospital in western Santa Catarina, through semi-structured interviews with nine nurses. In the data analysis, it was used the Discourse of the Collective Subject.

Results: Difficulties and potentialities in the implementation of the nursing process were identified, standing out as a support strategy for the elaboration of study groups for the permanent education of professionals. About the difficulties, it was highlighted the lack of theoretical knowledge about the nursing process and basic disciplines that impact on the clinical evaluation of the patient stands out. Conclusion: The implementation proved to be satisfactory under the nurses' perception, generating an impact on the quality of care, patient safety, nursing records and professional visibility, despite the various barriers identified during its implementation. Keywords: Nursing process. Intensive care units. Nursing records. Nursing care. Nursing.

\section{RESUMO}

Objetivo: Compreender a percepção dos enfermeiros acerca da implementação do processo de enfermagem em uma Unidade de Terapia Intensiva.

Método: Estudo qualitativo, exploratório e descritivo. A coleta de dados ocorreu de fevereiro a março/2018, em uma Unidade de Terapia Intensiva de um hospital público do oeste catarinense, por meio de entrevistas semiestruturadas com nove enfermeiros. Na análise dos dados utilizou-se o Discurso do Sujeito Coletivo.

Resultados: Identificou-se dificuldades e potencialidades na implementação do processo de enfermagem, destacando-se como estratégia de apoio a elaboração de grupos de estudo para educação permanente dos profissionais. Sobre as dificuldades, destacou-se a falta de conhecimento teórico sobre o processo de enfermagem e disciplinas básicas que impactam na avaliação clínica do paciente. Conclusão: A implementação se mostrou satisfatório sob a percepção dos enfermeiros, gerando impacto na qualidade da assistência, segurança do paciente, registros de enfermagem e visibilidade profissional, apesar das diversas barreiras identificadas durante a sua implementação

Palavras-Chave: Processo de enfermagem. Unidades de terapia intensiva. Registros de enfermagem. Cuidados de enfermagem. Enfermagem.

\section{RESUMEN}

Objetivo: Comprender la percepción de los enfermeros sobre la implementación del proceso de enfermería en una Unidad de Cuidados Intensivos.

Método: Estudio cualitativo, exploratorio y descriptivo. La recolección de datos se realizó de febrero a marzo/2018, en una Unidad de Cuidados Intensivos de un hospital público en el oeste de Santa Catarina, a través de entrevistas semiestructuradas con nueve enfermeros. En el análisis de datos utilizó el Discurso del Sujeto Colectivo.

Resultados: Se identificaron dificultades y potencialidades en la implementación del proceso de enfermería, destacándose como una estrategia de apoyo para la elaboración de grupos de estudio para la educación permanente de profesionales. En cuanto a las dificultades, se destacó la falta de conocimiento teórico sobre el proceso de enfermería y las disciplinas básicas que impactan en la evaluación clínica del paciente.

Conclusión: La implementación demostró ser satisfactoria bajo la percepción de los enfermeros, generando un impacto en la calidad de la atención, la seguridad del paciente, los registros de enfermería y visibilidad profesional, a pesar de las diversas barreras identificadas durante su implementación.

Palabras clave: Proceso de enfermería. Unidades de cuidados intensivos. Registros de enfermería. Atención de enfermería. Enfermería. 


\section{口INTRODUCTION}

Although discussions on the Systematization of Nursing Care (SNC) and the Nursing Process (NP) have already been carried out previously, in Brazil, they started only in the 1970s, with the Basic Human Needs Theory through the Wanda Aguiar Horta(1).

Right after, in 1986, with the Nursing Professional Exercise Law, number 7,498/86, nursing prescription and nursing consultation are regulated as private nurses' activities ${ }^{(2)}$. In 2002, the Federal Council of Nursing (COFEN) released Resolution 272/2002, repealed by Resolution COFEN 358/2009, which regulates SNC and the implementation of NP in all health institutions where there is nursing activity, being currently composed by five steps: data collection or nursing history, nursing diagnosis, nursing planning, nursing implementation and evaluation ${ }^{(3)}$.

Only after these Resolutions it was possible to definitively establish the differentiation between SNC and NP, concepts that are often used inadvertently as synonyms ${ }^{(4)}$. Therefore, it is worth clarifying that SNC is the organization of professional work in terms of method, human resources and instruments, making it possible to operationalize the NP and the use of other work methodologies, such as: Standard Operating Procedures (SOP), assistance protocols, and other instruments and routines ${ }^{(3)}$. NP, on the other hand, is a methodological instrument that guides professional nursing care and documentation of professional practice, that is, an application methodology ${ }^{(3)}$.

Despite almost 50 years from the beginning of studies on NP in Brazil(5), a gap is still perceived between the production of knowledge and its applicability in practice. It is observed that although several discussions about the use of this methodology in health institutions, NP is still not considered as an inseparable part of the daily work of many nurses and members of the nursing team ${ }^{(6)}$.

The NP is a necessary tool for carrying out continuous and systematic care, including combining the use of technological resources with scientific knowledge for quality care, favoring the patient's recovery ${ }^{(7)}$. The NP organizes the work and the care process, constitutes professional identity, enhances scientific knowledge, supports decision making and public policy formation, enabling improvement in the quality of care ${ }^{(8)}$.

The ICU is a sector designed for patients in critical and unstable conditions who need invasive support and high-precision equipment. As a result, care for these patients is complex in order to maintain their vital functions. For nurses, patient care in the ICU is a daily challenge, as it requires greater skills and scientific knowledge, in view of the clinical complexity that needs control and attention. To maintain a quality and safe practice, the nurse must perform nursing care with organization, shared planning and structuring of assistance $e^{(7,9)}$.

In this way, the NP makes it possible to carry out this care through an appropriate and individualized practice with the adoption of care models, assisting in professionals' daily lives and facilitating the fulfillment of the needs of the critical patient. In addition, it makes it possible to combine the use of technological resources with theoretical knowledge, forming a powerful tool to favor continuous, systematic and quality care, supplying the complexity of the necessary care for these patients ${ }^{(7,9)}$.

Considering that the challenges for implementing NP in an ICU are even greater due to the ones generated by the clinical situation of the critical patient, where implications on life or death, accompanied by highly complex procedures and hard technologies, make its implementation even more distant ${ }^{(7,9)}$. And, aiming that a recent study, points out the scarcity of articles on nurses' perception of NP, being the majority, published for more than five years ${ }^{(10)}$.

As a result of these findings, added to the benefits brought by the implementation of the NP, already mentioned above, it is asked what factors interfere in the implementation of the $N P$, and from that, how these vulnerabilities can be overcome.

In the studied unit, the implantation of NP started in 2016, starting with the nursing history and later for the other stages. The implantation group was composed by nurses, students and teachers, with biweekly meetings, where case studies and permanent education activities were developed, seeking to qualify and advance in the implantation of the NP. At the time of data collection, the NP was in the process of being assessed and improved by the team.

Given this situation, it was sought to answer the following investigative question: What is the perception of nurses in an Intensive Care Unit about the implementation of the nursing process in their daily work? And as an objective to understand the nurses' perception about the implementation of the nursing process in their daily work, in an Intensive Care Unit.

\section{METHOD}

This is a qualitative, exploratory, and descriptive study, approved by the Research Ethics Committee (REC) of the Universidade Federal de Santa Catarina, under statement No.2,537,092 and CAAE: 79455017,4,0000,0121. The research followed the recommended by Resolution n.466, of December 12, 2012, of the National Health Council. 
It was developed in an ICU of a public hospital in Western Santa Catarina, where the NP was in the final phase of implementation/evaluation. The hospital was the first in the region to have the NP implanted, and the ICU was the pilot unit of this process. It has 344 beds for inpatients, with more than $85 \%$ of this total dedicated to the care of patients in the Unified Health System (SUS). The ICU has 17 inpatient beds for adult patients and serves as a practice field for undergraduate health courses.

The nursing team in this sector is composed by 12 professionals per shift, from these two nurse assistants and nine nursing technicians, also counting on a coordinating nurse who works 40 hours a week, the unit has nine nurses in total.

The study sample consisted by the nine nurses who worked in the ICU sector, since they all met the inclusion criteria: to work for a minimum of six months in the ICU and have experienced the implementation of the NP, and the exclusion criteria were who were on vacation or leave during the data collection period. We chose to interview only nurses, as they actively participated in the process of implementing all stages of the NP.

Data collection took place from February to March 2018. Nurses were previously invited, with the purpose of explaining aspects of the research, removing doubts and identifying those interested in participating in the study to sign the Free and Informed Consent Form (ICF).

Data collection was performed through individual-presential interviews, previously scheduled (morning, afternoon and/or night), in a place within the hospital environment, in a comfortable, reserved room and maintaining the participants' privacy. In the interview, semi-structured scripts were used, prepared by the main researcher, with an average duration of 30 minutes and audio recording. It is noteworthy that two nurses did not agree with the audio-recorded interview, opting for participation in the research by writing the answers to the semi-structured script that was used by the researcher during data collection.

The instrument in the form of a semi-structured script consisted by ten closed questions and one open question: "What is your assessment of the application/implementation of the Nursing Process in your daily work?", With the objective of identifying the sociodemographic data, academic training and proximity with the proposed theme.

The data were fully transcribed, using the Microsoft Word ${ }^{\circledast}$ software for data records. The participants' speeches were identified through "P1", for example, in which "P" refers to "Participant", and " 1 " is the order of the interviewee during data collection, that is, Participant 1, Participant 2, and so on. This strategy was adopted with the purpose of maintaining the confidentiality of the data corresponding to the interviews conducted.

In that same document, the Discourse of the Collective Subject (DCS) was used for data analysis and organization, in which the discourses were presented under the collective configuration. It is also worth noting that the DCS is a proposal for organization, tabulation and analysis of qualitative information that occurs from the extraction of central ideals and key expressions. The key-expressions are literal excerpts from the statement that reveal its essence, while the Central Idea $(\mathrm{Cl})$ is the expression used to describe the meaning of the discourse presented ${ }^{(11)}$.

Thus, the transcribed interviews were subjected to an in-depth reading by the study's researchers, and from this reading the extracts (or key-expressions) of greatest recurrence and importance for the phenomenon analysis of interest were collected, that is, the implementation of the NP in the study ICU.

After extracting the key-expressions, they were arranged in a table in which it was possible to compare excerpts from the speech of the different research participants. The reading of these passages now tabulated, was followed by the separation of similar key expressions, that is, that would utter the same $\mathrm{Cl}$. The key-expressions that belonged to the same $\mathrm{Cl}$ were again read. Afterwards, these excerpts were organized and written in order to synthesize a single collective discourse, or as it is called by Lefévre and Lefévre ${ }^{(11)}$, the DCS itself, in which the synthesis-speech written in the first person of the singular, composed by the key-expressions that have the same $\mathrm{Cl}$.

Key-expressions, $\mathrm{Cl}$ and DCS itself are not the only DCS methodological figures. There is also the anchoring, which is the manifestation of a theory in the professed discourse, that is, to base the discourse on assumptions, theories, concepts, or hypotheses. However, there are speeches that, so-called generic, cannot make emerge the anchoring ${ }^{(11)}$. This is the case of this research, where the anchoring of the speeches was not performed.

\section{RESULTS AND DISCUSSION}

The research results will be presented in the form of a $C D$, followed by a discussion concerning the topic of interest. The CDs were divided into three main categories: the implantation of $\mathrm{NP}$ in the ICU, the importance of nursing records, and the potentialities of using NP; each containing their $\mathrm{Cls}$. 


\section{The implantation of NP in the ICU}

Cl: The difficulties of implementing NP in the ICU

DCS 1: At first, this application in practice was very difficult, like every routine, like every new process. Nobody liked it, we had a lot of doubts. It was also difficult to pass on to the technicians this new organization, to clarify their doubts. The first six months of implementation were like this: another paper for us to fill, more work overload. Complicated of ourselves, as nurses, we accept the nursing process. The process is being performed, however, still in the adaptation phase of the entire team. This process has been overwhelming. We have to end up embracing a lot and end up not being able to cope. It takes work to be very bureaucratic (P1, P2, P3, P4, P6, P7, P8).

Even 50 years after the beginning of the NP implementation in Brazil ${ }^{(1,5)}$, studies still show the difficulties in its creation and implementation as a reality in health institutions, including the ICU ${ }^{(7,12)}$. Its implementation is full of obstacles, such as deficiency in the training of nursing professionals, lack of knowledge, lack of training, inadequate records of nursing care, conflicts of roles, difficulty in accepting changes, lack of credibility in nursing prescriptions, work overload and lack of support from the team and institution ${ }^{(1)}$.

The NP is based on technical-scientific knowledge and for its implementation it is necessary that nurses have knowledge about the NP steps and, in addition, know how to apply it in practice. Theoretical knowledge about NP is essential for its implementation, since the knowledge fragility and concept recognition, steps and applicability are limitations for its acceptance with the team ${ }^{(4,7,13)}$.

In addition, theoretical knowledge is essential to demystify the perception that NP delays the resolution of immediate demands ${ }^{(14)}$. The social representation of the NP to the nursing team is a factor directly related to its execution, since nurses who do not understand the meaning of the NP do not perform it in their daily practice ${ }^{(6)}$.

The literature shows that the hospital environment was the place with the most difficulty in implementing NP, due to the vertical integration between the service and the academy, together with the absence of a permanent education program that provides constant training and updates on the theme $e^{(1,7,10,12-13)}$

The work overload and the lack of time were identified in the DCS as obstacles to the implementation of the NP. This result is supported by the literature, which points out that among the main vulnerabilities for the implementation of NP is the lack of time, the large number of patients, the nurse's excessive assignments, the massive presence of nurses in bureaucratic activities, among other factors with less frequency $y^{(1,5,7,10,12,14-16)}$. This causes the NP to be seen as a bureaucratic task, which occupies the nurse, already responsible for several other demands, and "steals" time ${ }^{(6)}$.

In the DCS, the excerpt "one more paper for us to fill, more work overload" shows how the NP is perceived by the team. That is, a protocol assignment, as another duty/obligation to be fulfilled, which can generate displeasure, rejection, devaluation and resistance in the implementation of the NP (14). Just as the excerpt "gives work because it is very bureaucratic" shows that the NP is considered a bureaucratic activity, and not a tool for assistance work ${ }^{(10,12,16)}$.

Cl: Improving competences for the implementation and execution of the NP

DCS 2: We set up study groups to answer questions. We met every 15 to 20 days in the group and defined a nursing diagnosis, for example: risk of skin injury. It was very complex because then each question ended up expanding more, so we had to pick up the books again to clear up those doubts. But finally, after about three months, weended up adapting. The groups help in the process because we get together, we clear up some doubts, and, we generate greater knowledge in relation to this (P2, P3, P6, P7).

The nursing diagnosis is considered the most difficult and complex stage of NP, which is possibly associated with the fact of mobilizing an accurate clinical reasoning, since it relates the collected information to the patient's clinical conditions, being that this stage constitutes one of the greatest challenges for the professional ${ }^{(17)}$.

In this discourse, it was evidenced that knowledge gaps are an obstacle to the implementation of NP. In addition, it can be inferred that the absence of a permanent health education program for NP limits the performance of nurses during their clinical practice $\mathrm{e}^{(7,12-13,15)}$.

Permanent education in health aims at professional qualification for work, being, therefore, inserted in the context of the professionals' performance. Permanent education allows changes in the daily work to be achieved, aiming at improving the assistance provided. It has strategies that value the experience and knowledge of professionals, promotes interactions, and promotes the continuous updating of theoretical and practical knowledge, according to the need of the work context ${ }^{(18)}$. 
A study developed in an ICU in Piauí showed that the absence of permanent health education for the implementation of NP resulted in insufficient knowledge about NP, generating, in turn, disinterest and low adherence to the $\operatorname{method}^{(9)}$. Therefore, it is inferred that the training and educational processes focused on the care practice are directly related to the implementation of the NP, since knowledge is essential for understanding the importance of this instrument, for the correct registration of $\mathrm{NP}$ information, and consequently, for improving the quality of care provided ${ }^{(1,9-10)}$.

Another study showed that knowledge limitations, specifically in the patient's clinical assessment, is one of the causes for the difficulty in implementing NP ${ }^{(10)}$. This situation is also identified in this study, since nurses cited knowledge gaps in basic disciplines (such as physiology, anatomy, and pathophysiology), hamper the patient's clinical assessment and, consequently, the execution and registration of NP.

Therefore, nurses developed training strategies through study groups, so that they could resume the theoretical content of the basic disciplines and conduct training for the execution and registration of NP. In the participants' perception, this initiative was important for strengthening knowledge and had a positive impact on the implementation of the NP.

\section{The importance of nursing records}

\section{$\mathrm{Cl}$ : The NP records and the profession visibility}

DCS 3: Most things we already did, we just didn't register.
Now, after the implantation of the NP, we have everything
documented, everything on paper. In fact, the Nursing
Process is the record of nursing performance with the
patient, formalizing and proving all the work done. As
it says, the Nursing Process is not just a document, it is
a record, it is the performance, it is the face of nursing. It
is necessary for nursing to have recognition (P2, P3, P4,
$P 6, P 7, P 8, P 9)$.

Nursing records are essential for the NP, a professional duty and a legal document about the assistance provided. In addition, records are an important means of communication for the team, ensuring continuity of care ${ }^{(16)}$.

Although the proper registration generates benefits for professional practice, professionals give little importance to this assignment, failing to do them or performing it incompletely ${ }^{(11)}$. Inadequate records are also reflected in practice, generating: discontinuity of care, inadequate assessment of changes in the patient's clinical condition, imprecise judgment of the results and absence of a legal basis for legal decisions ${ }^{(8)}$. Therefore, it has an impact in the assistance, financial, legal and administrative scope ${ }^{(16)}$.

Still in legal terms, the Resolution COFEN 358/2019 indicates that the NP documentation must be formally and imperatively registered, containing a summary of the data collected about the person, family or human collectivity at a given moment in the health and disease process; the Nursing Diagnoses; nursing interventions performed in relation to the identified NDs; and the results achieved as a result of the nursing actions or interventions performed ${ }^{(3)}$.

In DCS 3, it is evident that in the nurses' perception there is a directly proportional relationship between the nursing records and the visibility of the profession, which in turn impacts on the recognition of the importance of the nursing professional ${ }^{(3)}$. That is, nursing makes its work more visible when it shows the data resulting from its clinical evaluation and its performance. In this way, it provides information, reflects on the data collected and establishes priorities ${ }^{(19)}$.

The professional visibility of nurses is manifested through their scientific knowledge, their participation in the decision-making process and in management and coordination activities. In addition, it has its visibility expressed by the articulating actions that develops in front of the multidisciplinary team, in order to provide the development of transversal actions and, consequently, a more comprehensive health care ${ }^{(19)}$.

However, it is necessary to reflect on the importance of professional visibility in common sense, since the knowledge and clinic's applicability, as a field of practice and knowledge in health, is still often perceived by society as a field of medical domain. In this sense, nurses often have their performance confused with that of the doctor, or else, they are placed in a position of subordination ${ }^{(19)}$.

The collective imagination is of great importance in the acceptance and recognition of nurse ${ }^{(19)}$. And the professional visibility is necessary so that the nurse is encouraged to change and improve health systems, in the quality of care provided and patient safety ${ }^{(20)}$.

Therefore, in the nurses' perception, the implementation of NP contributed so that nursing activities were properly registered and documented, legally supporting the professional and giving visibility and recognition to their performance.

\section{The potentialities of using NP}

Cl: The importance of NP for improving the quality of care

DSC 4: The nursing process has been contributing so that we nurses can provide quality care. We can get to know our patient better through the nursing history, which 
brings us a little more information about patients in order to be able to better apply activities and have a better conduct in relation to this. Nursing care improved with the implantation. Now we register, evaluate, and it ends up forcing us to evaluate more, because at least every two days we have to make the scales (Braden and others). The prescription is daily, and it is necessary to look at the patient better. But also because the patient gained a lot from it, something that is having an effective result, that those interventions that we are applying there are indeed important for the patient (P1, P2, P3, P4, P5, P6, P7, P8).

In the nurses' perception, the implantation of NP in the ICU is a facilitator of care practices and improves the quality of care. This finding could be verified in other studies which show a significant improvement in the nursing care provided to the patient through the NP, further favoring the valorization and strengthening of the profession as a science ${ }^{(1,5,10,12-13,15,20) \text {. }}$

This is due to the activities planning and organizational structure resulting from the use of NP in the daily work, since, NP demands the establishment of a theoretical-philosophical basis and the use of technical-scientific knowledges to perform nursing care, with an ethical commitment to care for others ${ }^{(1,20)}$. Therefore, it implies safety and quality in the planning, execution and evaluation of nursing actions ${ }^{(3)}$.

These potentialities arising from the implementation of the NP gain special importance when applied in the ICUs. This is due to the characteristics of patients under critical health conditions, in which the severity of the clinical condition and the numerous interventions to which these patients are exposed (mechanical ventilation, use of vasoactive drugs, hemodialysis, among others) demands care even more systematic and accurate. While the patient's clinical changes can occur abruptly, which requires from professional a refined look to detect important changes and also agility to intervene in urgent situations ${ }^{(7)}$. Therefore, the implementation of systematic care through NP is an essential tool for intensive care nurses.

In a previous study, it was evidenced that, before the implementation of the NP, nurses had limited knowledge about the patient's clinic. However, with the implementation of NP, nurses were driven to a more in-depth data collection, as well as a thorough clinical evaluation ${ }^{(10)}$. This same evidence is present in DCS 4 when it reads "itends up forcing us to evaluate more".

There was still a need for nurse to continuously evaluate the patient using a more investigative approach, as evidenced in the section "it is necessary to look at the patient better".
Therefore, the professional needs to know in more detail the patient and his family in their biopsychosocial aspects, which consequently promotes the bond between professional-patient and improves the nurse's communication with the other professionals of the multidisciplinary team ${ }^{(1)}$.

Another potentiality identified in the implementation of the NP was the provision of nursing care with agility and ease in the actions developed ${ }^{(1,5)}$. Action planning avoids rework, as it directs the professionals' conduct through clinical evaluation and planning, resulting in targeted and better quality decision making, and which allows for daily re-planning through daily reevaluation or whenever necessary, both in terms of human care and the physical and material resources inserted in the process $s^{(1,5,13,20)}$.

Therefore, the potentialities arising from the implementation of NP, whether they are evidenced in DCS 4 or pointed out in the literature, can be described as: nurse autonomy, secure support through the nursing record, recognition by other professionals due to the greater visibility of the nurse's work, organizational uniformity, decrease in hospital stay and, consequently, cost savings $s^{(1,5,10,12,20)}$.

\section{FINAL CONSIDERATIONS}

The nurses realized that the implementation and application of the NP in this ICU allowed the improvement of the quality of care, the knowledge about the patient was deepened, as well as there was an improvement in the knowledge and clinical reasoning for the NP execution and increased professional visibility through the NP records.

It is noteworthy that the use of the study group strategy adopted by nurses during the implementation of NP, proved to be positive with potential for use in new contexts and with greater detail in future studies.

The reflections constitute a body of knowledge relevant to nursing care by highlighting the improvements obtained in care after the implementation of the Nursing Process, through scientifically based care, as well as professional recognition through appropriate records.

The research can contribute to the qualification of nursing care, since the nursing process implemented in the ICU allows nurses to recognize the demands imposed on daily care, for planning and decision making focused, resolutive and effective to intensive care.

It is recommended to explore other realities, including researches with a larger number of participants and diversifying services in order to add value to the NP, which can solidify the nurses'speeches and also have a more significant impact to the research. 


\section{REFERENCES}

1. Marinelli NP, Silva ARA, Silva DNO. Sistematização da Assistência de Enfermagem: desafios para a implantação. Rev Enferm Contemp. 2015 [cited 2020 Mar 10];4(2):254-63. Available from: https://www5.bahiana.edu.br/ index.php/enfermagem/article/view/523/553

2. Presidência da República (BR). Lei n. 7.498/86, de 25 de junho de 1986. Dispõe sobre a regulamentação do exercício da Enfermagem e dá outras providências. Brasília, DF; 1986 [cited 2020 Mar 10]. Available from: http://www.cofen.gov. br/lei-n-749886-de-25-de-junho-de-1986_4161.html

3. Conselho Federal de Enfermagem (BR). Resolução COFEN 358/2009. Dispõe sobre a Sistematização da Assistência de Enfermagem e a implementação do Processo de Enfermagem em ambientes, públicos ou privados, em que ocorre 0 cuidado profissional de Enfermagem, e dá outras providências. Brasília, DF: Cofen; 2009 [cited 2020 Mar 10]. Available from: http://www.cofen.gov.br/ resoluo-cofen-3582009_4384.html

4. Moser DC, Silva GA, Maier SRO, Barbosa LC, Silva TG. Nursing care systematization: the nurses' perception. J Res Fundam Care Online 2018;10(4):998-1007. doi: https://doi.org/10.9789/2175-5361.2018.v10i4.998-1007

5. Santos MG, Bitencourt JVOV, Silva TG, Frizon G, Quinto AS. Etapas do processo de enfermagem: uma revisão narrativa. Enferm Foco. 2017 [cited 2020 Mar 10];8(4):49-53. Available from: http://revista.cofen.gov.br/index.php/ enfermagem/article/view/1032

6. Costa, AC, Silva, JV. Nurses'social representations of nursing care systematization. Rev Enferm Refer. 2018;IV(16):139-46. doi: https://doi.org/10.12707/riv17069

7. Nunes RM, Nunes MR, Assunção IA, Lages LS. Sistematização da assistência de enfermagem e os desafios para sua implantação na unidade de terapia intensiva: uma revisão de literatura. Rev UNINGÁ. 2019 [cited 2020 Mar 10];56(S2):80-93. Available from: http://revista.uninga.br/index.php/uninga/article/view/2179/1903

8. Azevedo OA, Guedes ES, Araújo SAN, Maia MM, Cruz DALM. Documentation of the nursing process in public health institutions. Rev Esc Enferm USP. 2019;53:e03471. doi: https://doi.org/10.1590/S1980-220X2018003703471

9. Viana MRP, Ferreira TRS, Silva IMB, Amorim FCM, Soares E0. The operation of the nursing care process in the intensive care unit maternal. J Res Fundam Care Online. 2018;10(3):696-703. doi: https://doi.org/10.9789/2175-5361.2018.v10i3.696-703

\section{- Note:}

This article is part of the master's thesis results: Accuracy of nursing diagnoses in the intensive care unit, of the Graduate Program in Nursing at the Universidade Federal de Santa Catarina.

\section{- Funding:}

This work was supported by the Coordination for the Improvement of Higher Education Personnel - Brazil (Coordenação de Aperfeiçoamento de Pessoal de Nível Superior - CAPES) - Funding Code 001.

\section{- Corresponding author:}

Alexsandra Martins da Silva
10. Boaventura AP, Santos PA, Duran ECM. Theoretical and practical knowledge of the nurse on Nursing Process and Systematization of nursing. Enferm Glob. 2017;16(2):182-216. doi: https://doi.org/10.6018/eglobal.16.2.247911

11. Lefévre F, Lefévre AMC. 0 discurso do sujeito coletivo: um novo enfoque em pesquisa qualitativa (desdobramentos). 2. ed. Caxias do Sul: EdUCS, 2005.

12. Benedet SA, Gelbcke FL, Amante LN, Padilha MIS, Pires DP. Nursing process: systematization of the nursing care instrument in the perception of nurses. J Res Fundam Care Online. 2016;8(3):4780-8. doi: https://doi.org/10.9789/21755361.2016.v8i3.4780-4788

13. Almeida BP,Dias FSB, Cantú PM, Duran ECM, Carmona EV. Attitudes of nurses from a public teaching hospital regarding the nursing process. Rev Esc Enferm USP. 2019;53:e03483. doi: https://doi.org/10.1590/S1980-220X2018018203483

14. Oliveira CS, Borges MS. Social representations of systematization of nursing care in the perspective of nurses who take care of children. Rev Gaúcha Enferm. 2019;38(3):e66840. doi: https://doi.org/10.1590/1983-1447.2017.03.66840

15. Toney-Butler TJ, Unison-Pace WJ. Nursing Admission Assessment and Examination. In: StatPearls [Internet]. StatPearls Publishing, Treasure Island (FL); 2019 [cited 2020 Jul 09]. Available from: https://www.ncbi.nlm.nih.gov/ books/NBK493211/

16. Silva AGI, Dias BRL. Registros de enfermagem: uma revisão integrativa da literatura. Rev Nursing. 2018 [cited 2020 Mar 10];21(246):2476-81. Available from: http://www.revistanursing.com.br/revistas/247/pg30.pdf

17. Ubaldo I, Matos E, Salum NC. NANDA-I nursing diagnoses based on Wanda Horta's theory. Cogitare Enferm. 2015;20(4):687-94. doi: https://doi. org/10.5380/ce.v20i4.40468

18. Campos KFC, Marques RC, Ceccim RB, Silva KL. Educação permanente em saúde e modelo assistencial: correlações no cotidiano de serviço na Atenção Primária à Saúde. APS Rev. 2019;1(2):132-40. doi: https://doi.org/10.14295/aps.v1i2.28

19. Sousa LD, Lunardi Filho WD, Thofehrn MB. Visibility of nursing work in the context of the clinical model of health care. Rev Enferm UERJ. 2015;23(3):40712. doi: https://doi.org/10.12957/reuerj.2015.6100

20. Adamy EK, Zocche DAA, Almeida MA. Contribution of the nursing process for the construction of the identity of nursing professionals. Rev Gaúcha Enferm. 2020;41(esp):e20190143. doi: https://doi. org/10.1590/1983-1447.2020.20190143
Email: alexsandrams.enf@gmail.com

\section{Associate editor:}

Cecília Helena Glanzner

Editor-in-chief:

Approved: 08.19.2020
Maria da Graça Oliveira Crossetti 